\title{
Organ Measurements Reason Not Done
}

National Cancer Institute

\section{Source}

National Cancer Institute. Organ Measurements Reason Not Done. NCI Thesaurus.

Code C119891.

The explanation given as to why an organ measurement was not performed. 